\title{
Proses Berpikir Kreatif Siswa SMP dalam Memecahkan Masalah Numerasi Ditinjau dari Adversity Quotient (AQ)
}

\author{
Vania Idelia Cahyati ${ }^{1}$, Tatag Yuli Eko Siswono ${ }^{2}$ \\ ${ }^{1,2}$ Program Studi Pendidikan Matematika, Fakultas Matematika dan Ilmu Pengetahuan Alam, Universitas Negeri Surabaya, \\ J1. Lidah Wetan, Lidah Wetan, Kec. Lakarsantri, Kota SBY, Jawa Timur, 60213, Indonesia \\ vaniaidelia@gmail.com
}

\begin{abstract}
The creative thinking process is an individual's activity while doing thinking activities that produce creativity in solving problems where the stages include synthesizing ideas, building ideas, planning implementation, and implementing ideas. The creative thinking process of each individual in solving problems is different from one another and it can be seen through his Adversity Quotient (AQ). The purpose of this study is to describe the creative thinking process of junior high school students with AQ quitter, camper, and climber in solving numeracy problems. This qualitative descriptive study took three subjects, namely students with different AQ categories. Data was collected by giving ARP questionnaires, numeracy problem-solving tests, and interviews. Data analysis was carried out using the concept of the Pierce sign. The results show that at the stage of synthesizing the idea camper and climber subjects make the crucial information separate, at the stage of building the idea of quitter and climber subjects linking the concept of knowledge to problem-solving, at the stage of planning the application of camper the subject and advanced knowledge build a strategy based on information and knowledge concepts it has, at the stage of applying quitter's subject idea of surrendering, and then camper subject chooses to use another strategy that is considered easier, whereas climber subject chooses to use a strategy that he has already devised must be considered difficult. Through research results, teachers can enhance student enthusiasm by giving special motivation to quitter and camper students and teachers can give camper students more problem-solving exercises that relate to daily life.
\end{abstract}

Keywords: creative thinking process, problem-solving, numeracy, adversity quotient

\begin{abstract}
Abstrak
Proses berpikir kreatif merupakan kegiatan seseorang ketika melakukan aktivitas berpikir yang menghasilkan suatu kreativitas dalam memecahkan masalah yang tahapannya meliputi mensintesis ide, membangun ide, merencanakan penerapan, dan menerapkan ide. Proses berpikir kreatif setiap individu dalam memecahkan masalah berbeda satu dengan lainnya dan dapat dilihat melalui adversity quotient (AQ) yang dimilikinya. Tujuan penelitian ini adalah mendeskripsikan proses berpikir kreatif siswa SMP dengan AQ quitter, camper, dan climber dalam memecahkan masalah numerasi. Penelitian deskriptif kualitatif ini mengambil tiga subjek yaitu siswa dengan katergoti AQ berbeda. Pengumpulan data dilakukan dengan memberikan angket ARP, tes pemecahan masalah numerasi, dan wawancara. Analisis data dilakukan menggunakan konsep tanda Pierce. Hasil penelitian menunjukkan pada tahap mensintesis ide subjek camper dan climber melakukan pemisahan informasi penting, pada tahap membangun ide subjek quitter dan climber mengaitkan konsep pengetahuan yang dimiliki, pada tahap merencanakan penerapan subjek camper dan climber membuat rancangan strategi berdasarkan informasi dan konsep pengetahuan yang dimiliki, pada tahap menerapkan ide subjek quitter mengambil keputusan menyerah, subjek camper memilih untuk menggunakan strategi lain yang dianggap lebih mudah, dan subjek climber memilih untuk menggunakan strategi yang telah ia rencanakan meski sulit. Melalui hasil penelitian, guru dapat menaikkan antusias siswa dengan memberikan motivasi khusus pada siswa sesuai dengan kategori AQ.
\end{abstract}

Kata kunci: proses berpikir kreatif, pemecahan masalah, numerasi, adversity quotient

Copyright (c) 2022 Vania Idelia Cahyati, Tatag Yuli Eko Siswono

$\triangle$ Corresponding author: Vania Idelia Cahyati

Email Address: vaniaidelia@gmail.com (Jl. Mustiko, RT.03/RW.01, Kec. Badas, Jawa Timur 64224)

Received 06 January 2022, Accepted 26 January 2022, Published 08 February 2022

\section{PENDAHULUAN}

Berpikir kreatif saat ini merupakan salah satu Standar Kompetesi Kelulusan pada kurikulum 2013 dan telah menjadi tuntutan yang harus dikuasai pada abad ke-21. Hal tersebut didukung dengan 
pernyataan McGregor (2007) yakni dalam dunia pendidikan diharapkan siswa difokuskan kepada penguasaan berbagai keterampilan berpikir seperti berpikir kritis, berpikir kreatif, dan kemampuan pemecahan masalah. Tetapi yang terjadi saat ini adalah upaya peningkatan berpikir kreatif dalam matematika masih jarang bahkan belum menjadi fokus untuk dikembangkan (Siswono, 2008)

Krulik, Stephen, Rudnick, Jesse \& Milou (2003) mengungkapkan bahwa berpikir kreatif merupakan salah satu tingkatan berpikir yang paling tinggi. Csikszentmihalyi (1997) mendefinisikan berpikir kreatif sebagai suatu aktivitas menghasilkan ide baru berdasarkan pengetahuan yang telah dimiliki, ataupun dengan memanfaatkan pengetahuan lain namun tetap sesuai dengan aturan dan prosedur yang ada. Sedangkan Innovation (2001) berpendapat bahwa berpikir kreatif merupakan suatu proses mendapatkan atau menemukan ide baru yang dilakukan oleh seorang individu, dimana ide baru tersebut merupakan gabungan dari ide yang pernah ada ataupun ide yang belum pernah direlisasikan. Berpikir kreatif dalam penelitian ini merupakan aktivitas seorang individu untuk mendapatkan atau menghasilkan ide dari pengalaman atau pengetahuan yang telah dimiliki sebelumnya dengan tetap memperhatikan aturan dan prosedur yang ada.

Siswono (2002) mengatakan proses berpikir merupakan suatu proses dimana data akan diterima kemudian diolah dan disimpan dalam ingatan, kemudian jika suatu saat data tersebut dibutuhkan ketika akan diolah lagi maka dapat dipanggil kembali dari ingatan. Tahapan proses berpikir kreatif terdiri atas mensintesis ide, membangun ide, merencanakan penerapan, dan menerapkan ide. Mensitesis ide berarti seorang individu akan mengumpulkan semua ide yang berasal dari pengetahuan yang dimiliki sebelumnya maupun dari pengalaman dalam kehidupan sehari-hari, pada tahap ini seorang individu telah memahami masalah dan memiliki beberapa pengetahuan yang dibutuhkan dalam memecahkan masalah. Membangun ide berarti seorang individu dapat memunculkan lebih dari satu ide yang berkaitan dengan masalah sebagai hasil dari sintesis ide. Merencanakan penerapan berarti seorang individu telah memilih satu dari beberapa ide yang telah dimunculkan sebelumnya untuk digunakan dalam memecahkan masalah, dan menerapkan ide berarti seorang individu telah menggunakan ide yang dipilih sebelumnya dalam memecahkan masalah (Siswono, 2008).

Dahar (2011) mengungkapkan bahwa memecahkan masalah pada dasarnya merupakan tujuan utama dari proses pendidikan. Briggs, M. \& Davis (2007) dalam penelitiannya menyebutkan bahwa kemampuan berpikir kreatif dapat ditingkatkan melalui aktivitas memecahkan masalah. Seorang individu akan melakukan proses berpikir ketika memecahkan masalah sampai dengan ditemukannya penyelesaian, hal tersebut dikarenakan dengan adanya masalah maka otak akan berlatih memproses informasi (Puspitasari \& Sulaiman, 2019).

Steen (2002) telah mendefinisikan numerasi sebagai suatu kemampuan penalaran kuantitatif yang dimiliki seorang individu dimana hal tersebut sangat dibutuhkan dalam kehidupan sehari-hari. Numerasi seringkali dikenal sebagai kemampuan seseorang dalam mendefinisikan dan memakai bilangan secara langsung di kehidupan (Askew \& Millett, 2004).

Proses berpikir kreatif dan kemampuan pemecahan masalah numerasi pada setiap individu 
berbeda antara satu dengan yang lain sehingga kendala atau tantangan yang dihadapi antara satu individu dengan individu yang lain juga akan berbeda. Stoltz (2000) dalam penelitiannya menyimpulkan bahwa seorang individu memiliki kecerdasan dalam menghadapi kesulitan yang selanjutnya dikenal sebagai Adversity Quotient (AQ). Berdasarkan uraian di atas maka peneliti akan mendeskripsikan proses berpikir kreatif siswa SMP dengan kategori AQ quitter, camper, dan climber dalam memecahkan masalah numerasi.

\section{METODE}

Penelitian ini merupakan penelitian deskriptif kualitatif. Sumber data dalam penelitian ini adalah siswa kelas IX SMPN 4 Pare Kediri. Subjek penelitian akan dipilih menggunakan purposive sampling dengan variansi maksimal, subjek yang diambil adalah satu siswa berbeda pada setiap kategori AQ meliputi quitter yakni siswi dengan inisial DFA, camper yakni siswi dengan inisial DSP, dan climber yakni siswi dengan inisial AT dimana ketiganya berjenis kelamin perempuan karena dianggap dapat lebih berkomunikasi dengan baik, memiliki kemampuan matematika yang relative sama berdasarkan referensi dari guru matematika yang dilihat dari nilai rata-rata raport, dan dapat menjelaskan semua hal yang berkaitan dengan idenya selama memecahkan masalah numerasi dengan baik.

Penelitian ini menggunakan dua instrumen, yaitu peneliti sebagai instrumen utama dan tiga jenis teknik pengumpulan data yaitu angket Adversity Response Profile (ARP), tes pemecahan masalah numerasi, serta pedoman wawancara sebagai instrumen pendukung. Jenis teknik pengumpulan data pertama berupa angket Adversity Response Profile (ARP) diadopsi dari penelitian Sudarman (2011), selanjutnya terdapat tes pemecahan masalah yang terdiri dari satu soal numerasi dalam bentuk soal uraian dan harus diselesaikan dalam waktu 30 menit,
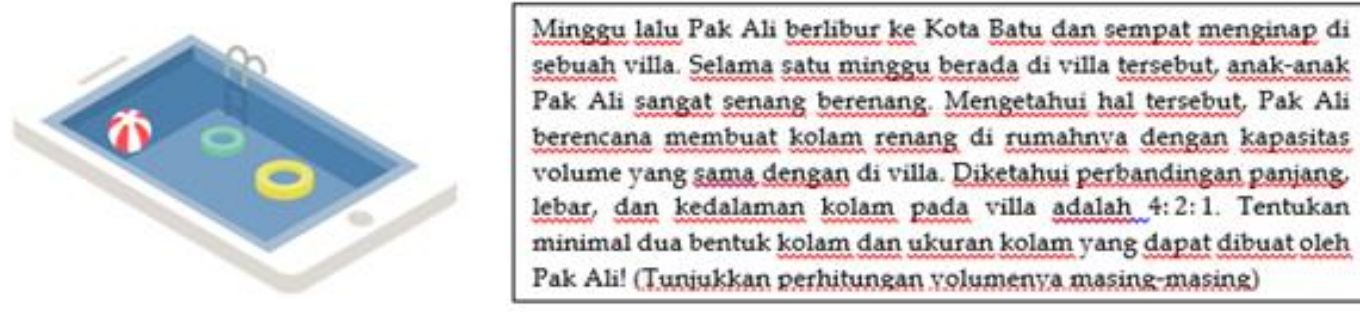

Gambar 1. Soal Tes Pemecahan Masalah

serta yang terakhir yaitu pedoman wawancara.

Tabel 1. Pedoman Wawancara

\section{Mensintesis Ide}

- siswa memahami masalah yang diberikan

- siswa mendapatkan informasi mengenai perbandingan dan volume

- siswa mulai mengumpulkan semua pengetahuannya mengenai berbagai macam bangun ruang, rumus mencari volume, dan menyelesaikan masalah perbandingan

- siswa menjelaskan ide yang terlintas dipikirannya untuk digunakan dalam memecahkan 
masalah

- siswa menjelaskan darimana ide yang terlintas tersebut didapatkan

\begin{tabular}{|l|l|l|l|}
\hline \multicolumn{1}{|c|}{ Pertanyaan } & Aksi Mental & \multicolumn{1}{c|}{$\begin{array}{c}\text { Ways of } \\
\text { Thinking }\end{array}$} & $\begin{array}{c}\text { Ways of } \\
\text { Understanding }\end{array}$ \\
\hline $\begin{array}{l}\text { 1. Coba soalnya dibaca terlebih } \\
\text { dahulu, apakah dapat dipahami? }\end{array}$ & $\begin{array}{l}\text { Mensintesis } \\
\text { (mengumpulkan } \\
\text { 2. Informasi apa saja yang kamu } \\
\text { dapatkan dari soal tersebut? } \\
\text { segala bentuk } \\
\text { informasi) }\end{array}$ & $\begin{array}{l}\text { Membaca } \\
\text { dengan seksama }\end{array}$ & kunci \\
3. Apa yang ditanyakan soal \\
$\begin{array}{l}\text { tersebut? } \\
\text { Ide yang bagaimana yang saat } \\
\text { ini terbesit di pikiran kamu } \\
\text { untuk memecahkan soal } \\
\text { tersebut? Coba dijelaskan }\end{array}$ \\
$\begin{array}{l}\text { Darimana ide yang kamu } \\
\text { pikirkan itu didapatkan? }\end{array}$
\end{tabular}

- siswa dapat menyusun beberapa strategi dari ide yang terlintas di pikiran pada tahap sebelumnya

\begin{tabular}{|l|l|l|l|}
\hline \multicolumn{1}{|c|}{ Pertanyaan } & \multicolumn{1}{|c|}{ Aksi Mental } & \multicolumn{1}{c|}{$\begin{array}{c}\text { Ways of } \\
\text { Thinking }\end{array}$} & \multicolumn{1}{c|}{$\begin{array}{c}\text { Ways of } \\
\text { Understanding }\end{array}$} \\
\hline $\begin{array}{l}\text { 6. Dari informasi yang ada dan ide } \\
\text { yang tadi sempat terpikirkan, } \\
\text { bagaimana saja susunan strategi } \\
\text { yang kamu miliki agar } \\
\text { masalahnya dapat diselesaikan? } \\
\text { Coba dijelaskan satu persatu }\end{array}$ & $\begin{array}{l}\text { Membangun } \\
\text { beberapa strategi } \\
\text { (berdasar ide hasil } \\
\text { sintesis) }\end{array}$ & $\begin{array}{l}\text { Berdiam, } \\
\text { Merenung, }\end{array}$ & \\
\hline
\end{tabular}

\section{Merencanakan Penerapan}

- $\quad$ siswa dapat menentukan strategi yang menurutnya paling mudah namun tetap akurat dalam memecahkan masalah yang disajikan

- siswa dapat menjelaskan langkah pertama yang diambil dalam memecahkan masalah

\begin{tabular}{|ll|l|l|l|}
\hline \multicolumn{1}{|c|}{ Pertanyaan } & \multicolumn{1}{c|}{ Aksi Mental } & \multicolumn{1}{c|}{$\begin{array}{c}\text { Ways of } \\
\text { Thinking }\end{array}$} & \multicolumn{1}{c|}{$\begin{array}{c}\text { Ways of } \\
\text { Understanding }\end{array}$} \\
\hline 7. $\begin{array}{l}\text { Menurutmu strategi yang } \\
\text { manakah yang paling mudah? }\end{array}$ & $\begin{array}{l}\text { Menyusun } \\
\text { penerapan dari } \\
\text { 8trategi yang } \\
\text { 8engapa strategi tersebut yang } \\
\text { menurutmu paling mudah? } \\
\text { Bagaiamanakah langkah awal } \\
\text { yang kamu ambil dari strategi } \\
\text { yang telah kamu pilih tesebut? }\end{array}$ & $\begin{array}{l}\text { Mencoret di } \\
\text { dipilih (langkah- } \\
\text { langkah) }\end{array}$ & Gambar Geometris \\
\hline & & & \\
\hline
\end{tabular}

- siswa telah mendapatkan hasil dari strategi yang telah ia pilih

- siswa membuktikan bahwa hasil yang telah didapatkan sama dengan permintaan pada soal

- siswa mencoba untuk membuktikan jawaban yang sama dengan strategi yang berbeda (bila ada) 


\begin{tabular}{|c|l|l|l|}
\hline \multicolumn{1}{|c|}{ Pertanyaan } & \multicolumn{1}{|c|}{ Aksi Mental } & \multicolumn{1}{c|}{$\begin{array}{c}\text { Ways of } \\
\text { Thinking }\end{array}$} & $\begin{array}{c}\text { Ways of } \\
\text { Understanding }\end{array}$ \\
\hline $\begin{array}{c}\text { 10. Dari strategi yang kamu pilih, } \\
\text { bagaimana hasil yang kamu } \\
\text { dapatkan? Apakah sudah sesuai } \\
\text { dengan yang diminta pada soal? }\end{array}$ & $\begin{array}{l}\text { Membuktikan } \\
\text { (mendapatkan } \\
\text { hasil dari strategi } \\
\text { yang telah }\end{array}$ & Mempraktikkan & $\begin{array}{l}\text { Jawaban akhir } \\
\text { (berupa gambar } \\
\text { geometris serta } \\
\text { perhitungan) }\end{array}$ \\
$\begin{array}{c}\text { 11. Misal menggunakan strategi } \\
\text { yang lain yang tidak kamu } \\
\text { pilih, apakah hasilnya akan } \\
\text { sama atau berbeda? Bisa coba } \\
\text { ditunjukkan }\end{array}$ & $\begin{array}{l}\text { memikirkan } \\
\text { kemungkinan jika } \\
\text { menggunakan } \\
\text { strategi yang } \\
\text { berbeda }\end{array}$ & & \\
\hline
\end{tabular}

Analisis data dalam penelitian ini, hasil angket Adversity Response Profile (ARP) akan dianalisis dengan menjumlahkan skor setiap siswa untuk dikelompokkan kedalam kategori quitter, camper, dan climber. Hasil tes pemecahan masalah numerasi akan dianalisis berdasarkan indikator kemampuan berpikir kreatif dalam memecahkan masalah numerasi, serta hasilsu wawancara akan dianalisis menggunakan konsep tanda Pierce yang disesuaikan dengan indikator proses berpikir kreatif.

\section{HASIL DAN DISKUSI}

\section{Proses Berpikir Kreatif Siswa Quitter}

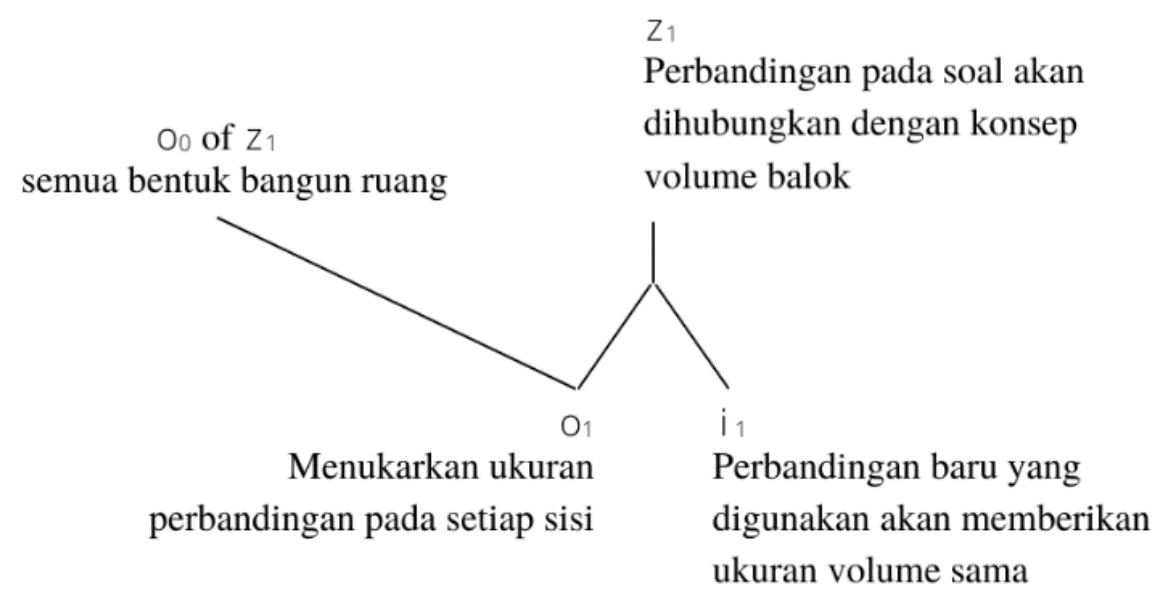

Gambar 1. Diagram Analisis Tahap Membangun Ide oleh DFA

Melalui $\mathrm{z}_{1}$ dapat dilihat bahwa DFA tidak membuat ukuran tertentu namun menggunakan perbandingan pada setiap sisi sebagai ukuran dari bangun baru yang akan dibuat olehnya. Selain itu, pada tahap ini DFA hanya terfokus pada bangun balok saja meski diketahui objek $\mathrm{o}_{0}$ dari $\mathrm{z}_{1}$ adalah semua bentuk bangun ruang. Sehingga didapatkan ruang interpretant yakni dengan menukarkan perbandingan, maka volume yang dihasilkan semua bangun baik pada soal maupun pada jawaban akan sama meski ukuran setiap sisi pada akhirnya antara bangun yang satu dengan bangun yang lain. 
Proses Berpikir Kreatif Siswa SMP dalam Memecahkan Masalah Numerasi Ditinjau dari Adversity Quotient (AQ), Vania

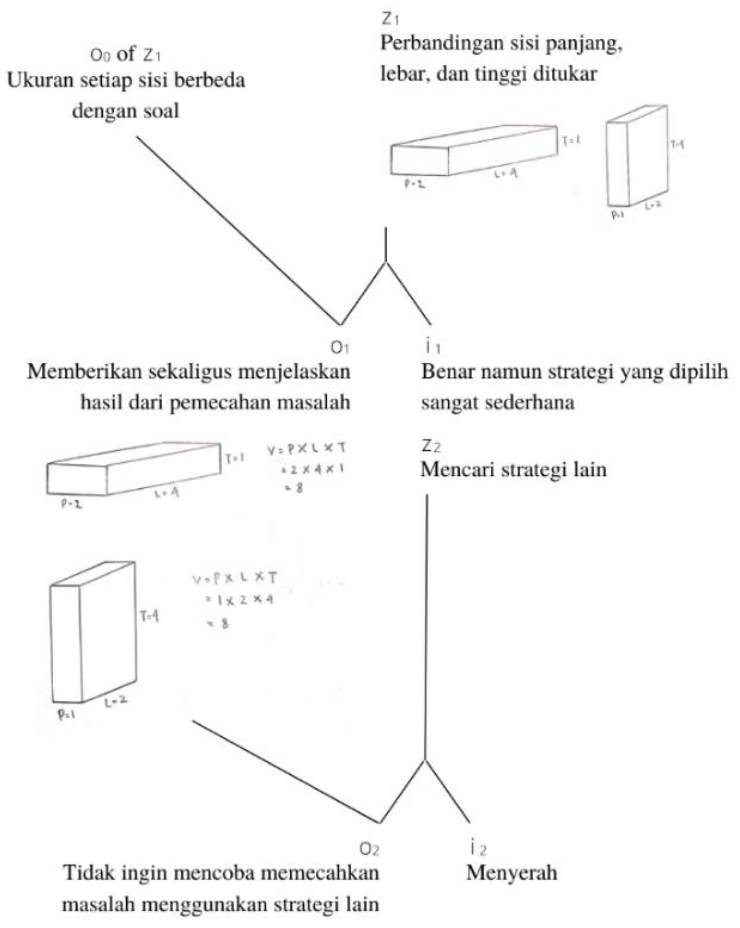

Gambar 2. Diagram Analisis Tahap Menerapkan Ide oleh DFA

Dapat dilihat bahwa DFA disini tidak memikirkan strategi lain dan memiliki keyakinan bahwa strategi yang ia pilih adalah yang paling mudah dan benar sehingga ruang interpretant dari $\mathrm{O}_{2}$ adalah DFA dianggap menyerah.

\section{Proses Berpikir Kreatif Siswa Camper}

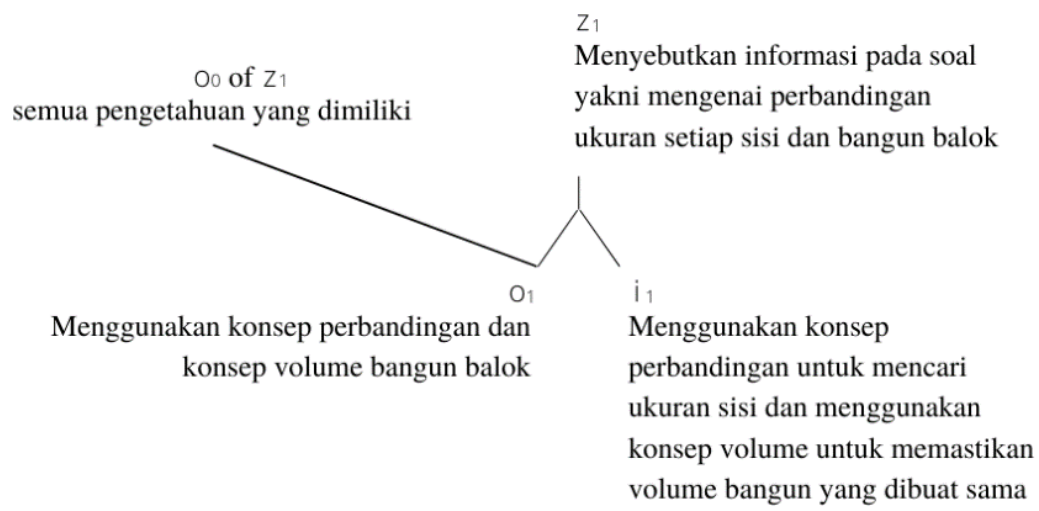

Gambar 3. Diagram Analisis Tahap Mensintesis Ide oleh DSP

Melalui $\mathrm{z}_{1}$ dapat dilihat bahwa DSP telah memahami soal. Kemudian diketahui pada objek matematika tentang $I_{k}$ ia dapatkan dari pengetahuannya yang berdasarkan pengalaman belajar di kelas. Ruang interpretant yang didapatkan adalah DSP akan menggunakan konsep perbandingan untuk mencari ukuran setiap sisi pada bangun balok yang diketahui kemudian menggunakan rumus volume untuk memastikan jika ukuran bangun yang ia buat berbeda tetap akan memiliki volume yang sama. 


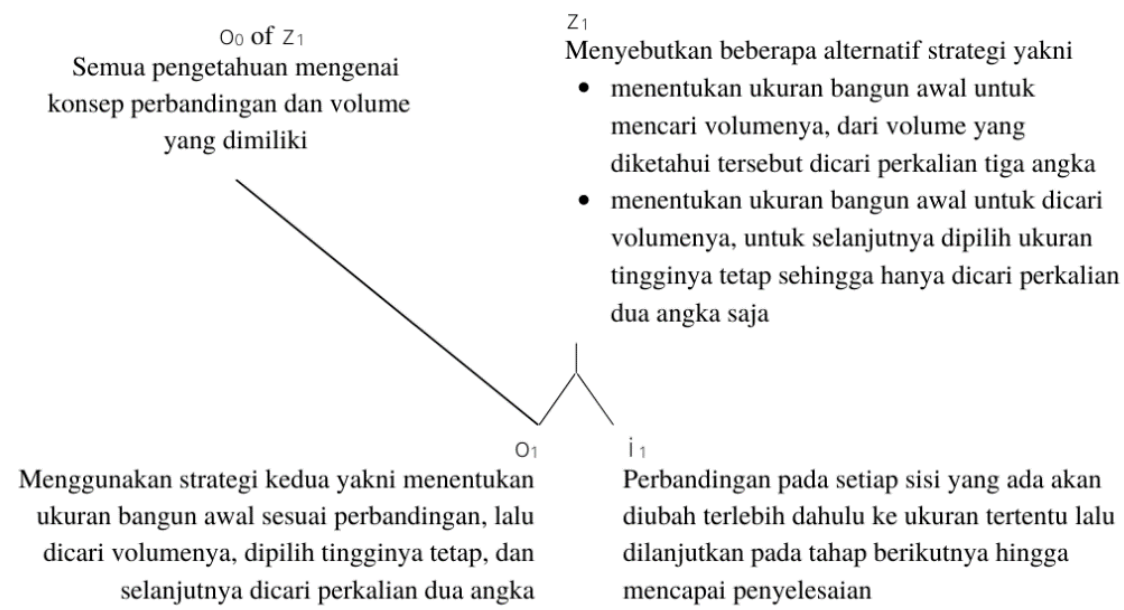

Gambar 4. Diagram Analisis Tahap Merencanakan Penerapan oleh DSP

Melalui $\mathrm{z}_{1}$ diketahui DSP telah memberikan gambaran mengenai dua alternative strategi yang ia pikirkan. Meski terlihat mirip, pada akhirnya objek matematika tentang $I_{k}$ yang didapatkan yakni "strategi kedua adalah yang paling mudah" karena DSP merasa hanya perlu mencoba-coba perkalian dua angka saja. Selanjutnya, DSP akan mulai mengambil langkah pertama yaitu menentukan ukuran sesuai dengan perbandingan pada soal, hal ini termasuk dalam ruang interpretant.

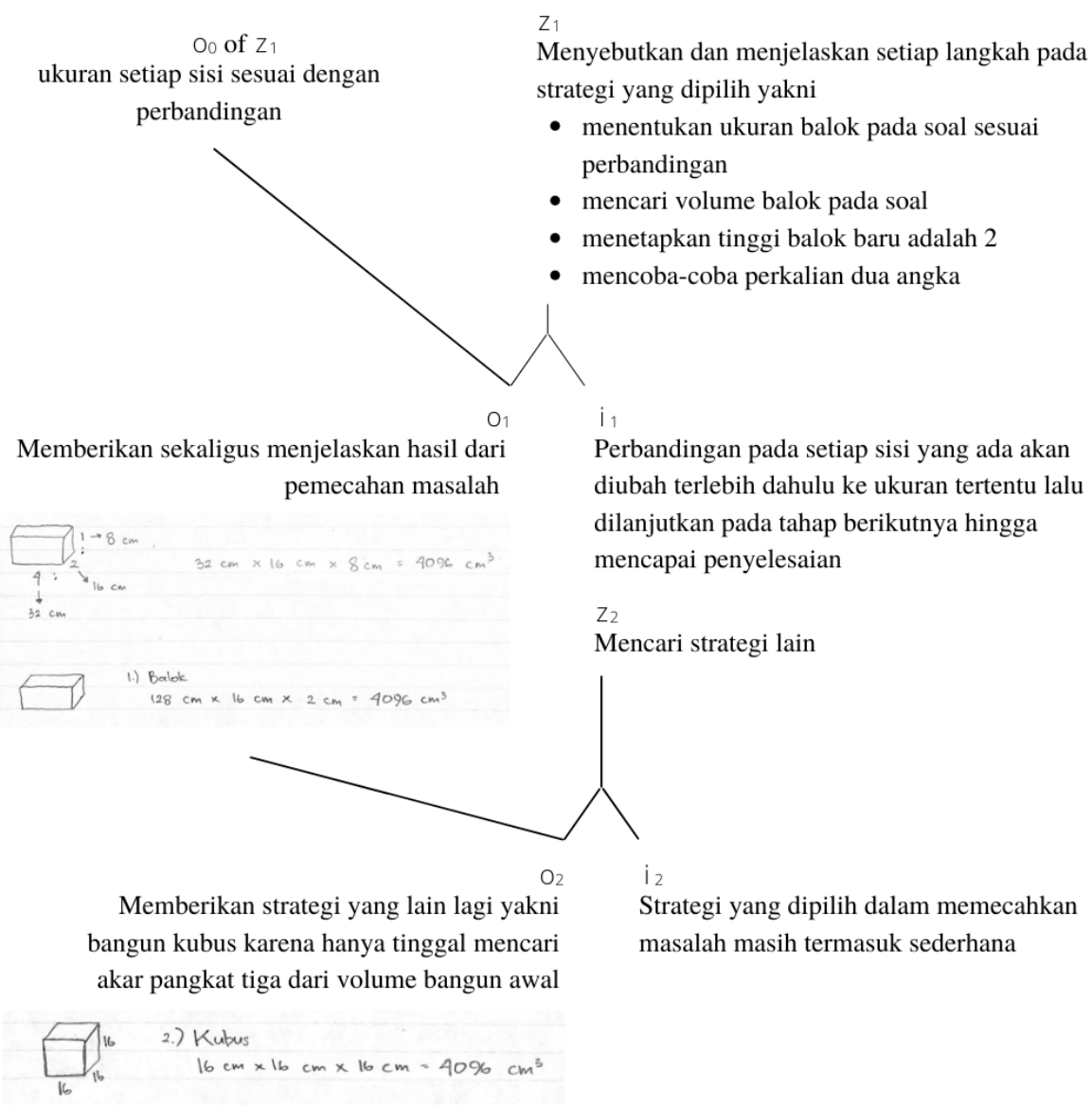

Gambar 5. Diagram Analisis Tahap Menerapkan Ide oleh DSP 
Melalui $\mathrm{z}_{1}$ DSP telah menjelaskan secara detail dari tahap ke tahap yang ia akan lakukan dalam memecahkan masalah sesuai dengan strategi yang telah ia pilih sebelumnya. Setelah DSP menjelaskan mengenai hasil dari pemecahan masalah yang ia lakukan, akan diberikan $\mathrm{z}_{2}=$ "mencari strategi lain" karena pada tahap merencanakan penerapan, DSP menyebutkan dua strategi. Namun ternyata pada objek matematika $\mathrm{o}_{1}$ tentang $\mathrm{I}_{1}$ DSP memberikan alternative strategi lain. Hasil dari dua strategi yang diberikan keduanya benar, namun didapatkan ruang interpretant dari $\mathrm{O}_{2}$ adalah DSP mudah menyerah

\section{Proses Berpikir Kreatif Siswa Climber}

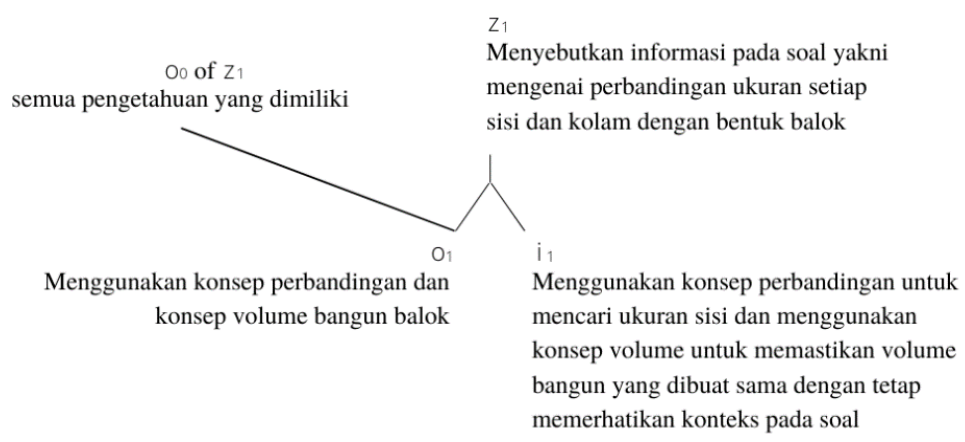

Gambar 6. Diagram Analisis Tahap Mensintesis Ide oleh AT

Melalui $\mathrm{z}_{1}$ dapat dilihat bahwa AT telah memahami dan memerhatikan soal yang berbentuk kontekstual, objek matematika tentang $\mathrm{I}_{\mathrm{k}}$ adalah "menggunakan konsep perbandingan dan konsep volume bangun balok" dan ruang interpretant yang didapatkan adalah AT akan menggunakan konsep perbandingan untuk mencari ukuran setiap sisi pada bangun balok yang diketahui kemudian menggunakan rumus volume untuk memastikan jika ukuran bangun yang ia buat berbeda tetap akan memiliki volume yang sama, hal tersebut ia lakukan dengan tetap memerhatikan konteks pada soal yakni mengenai bentuk kolam.

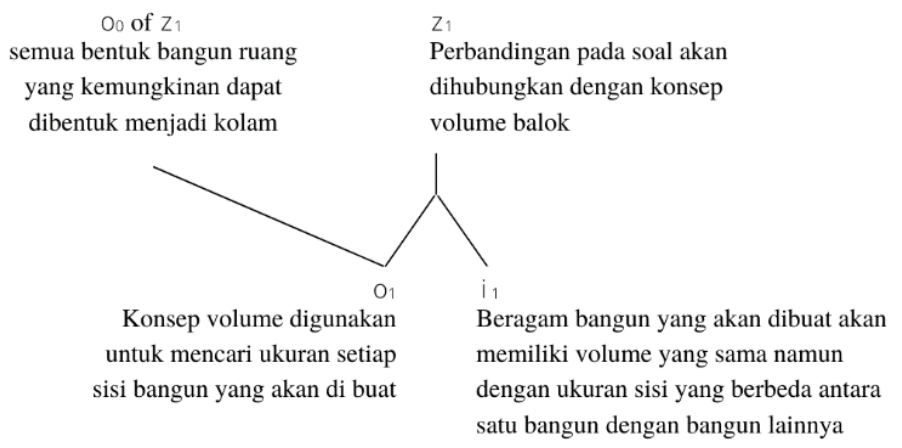

Gambar 7. Diagram Analisis Tahap Membangun Ide oleh AT

Melalui $\mathrm{z}_{1}$ dapat dilihat bahwa AT membuat ukuran tertentu berdasarkan perbandingan yang diketahui pada soal yang kemudian akan dihubungkan dengan konsep volume bangun balok. Objek matematika $o_{1}$ tentang $\mathrm{I}_{\mathrm{k}}$ adalah "konsep volume digunakan untuk mencari ukuran setiap sisi bangun 
yang akan dibuat" ketika AT akan memecahkan masalah. Ruang interpretant yang didapatkan adalah beragam bangun yang nantinya akan dibuat oleh AT akan selalu memiliki volume yang sama dengan ukuran setiap sisi yang berbeda antara bangun yang satu dengan bangun yang lainnya.

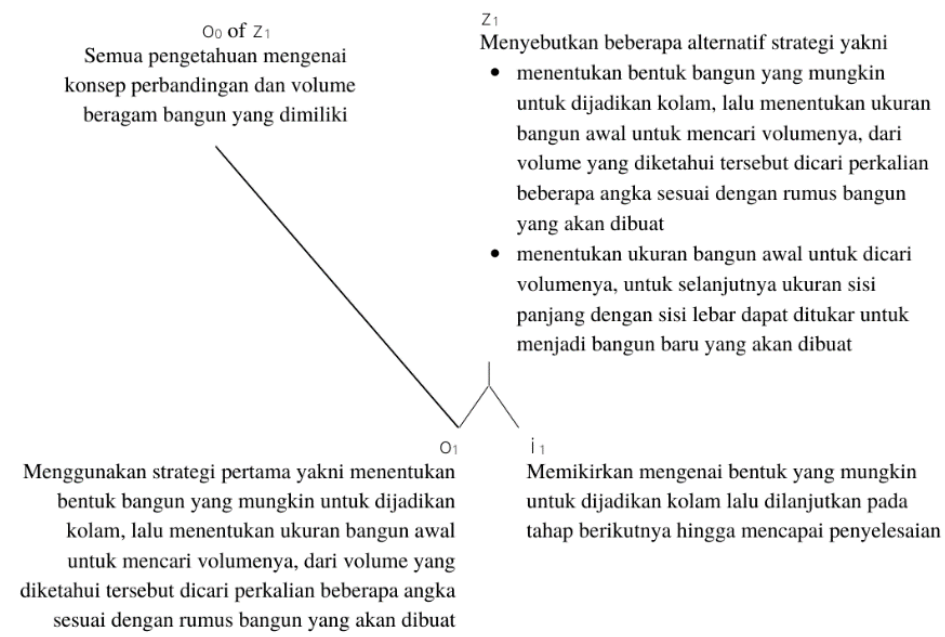

Gambar 8. Diagram Analisis Tahap Merencanakan Penerapan oleh AT

Melalui $\mathrm{z}_{1}$ diketahui AT telah memberikan gambaran mengenai dua alternative strategi yang ia pikirkan. AT merasa ragu jika hanya menukarkan ukuran panjang dan lebar saja apakah dapat dikatakan memiliki ukuran yang berbeda dan kemudian AT akan mulai mengambil langkah pertama yaitu memikirkan mengenai kemungkinan bentuk bangun yang dapat direalisasikan untuk menjadi kolam, hal ini termasuk dalam ruang interpretant.

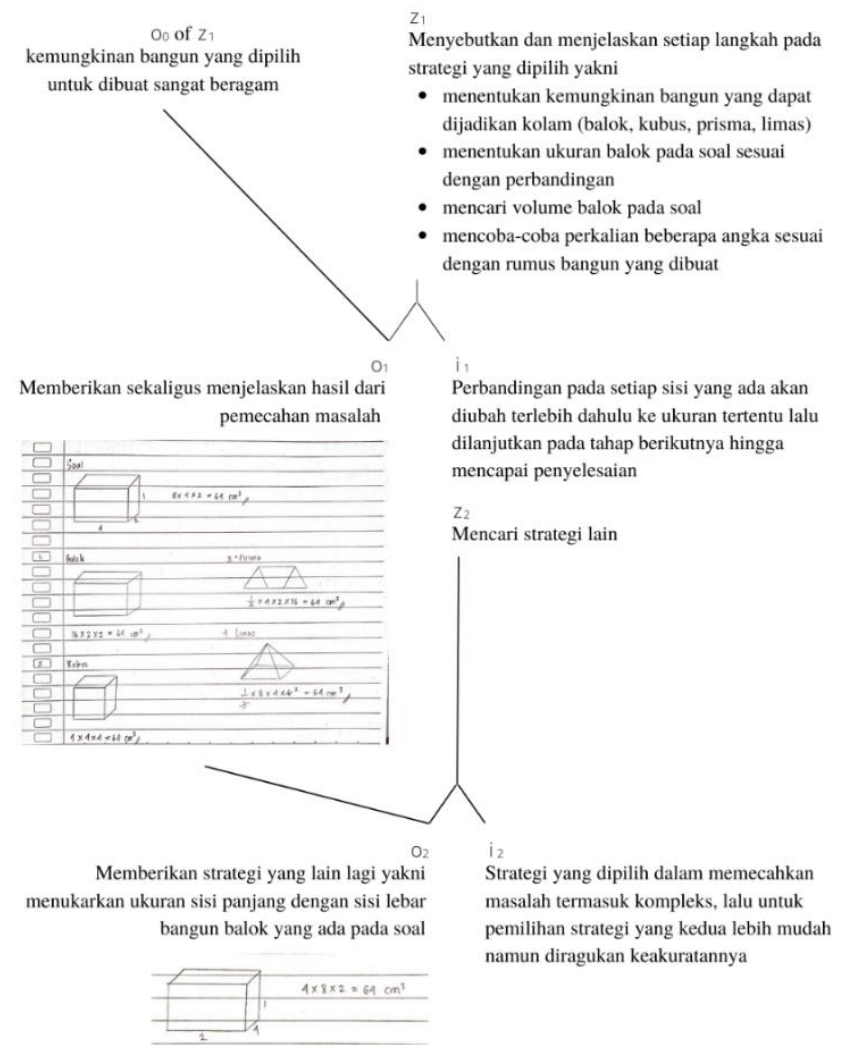

Gambar 9. Diagram Analisis Tahap Penerapan Ide oleh AT 
Melalui $\mathrm{z}_{1}=$ "menyebutkan dan menjelaskan tahapan dari strategi yang dipilih" diketahui AT telah menjelaskan secara detail dari tahap ke tahap yang ia akan lakukan dalam memecahkan masalah sesuai dengan strategi yang telah ia pilih sebelumnya. Setelah AT menjelaskan mengenai hasil dari pemecahan masalah yang ia lakukan, akan diberikan $\mathrm{z}_{2}$ dan hasil dari dua strategi yang diberikan keduanya benar, dan didapatkan ruang interpretant dari $\mathrm{o}_{2}$ adalah AT selalu berusaha memberikan hasil penyelesaian yang terbaik meski tahapan dari strategi yang dilalui kompleks

Berdasarkan hasil yang telah diketahui bahwa ketika mengerjakan DFA tidak melakukan aktivitas membuat sketsa namun selanjutnya DFA melakukan aktivitas merenung yang seperti tidak berarti dikarenakan setelahnya tidak melakukan pengerjaan lebih lanjut dan memilih untuk berhenti. Berdasarkan $\mathrm{z}_{4}$ "mencari strategi lain" dan $\mathrm{O}_{4}$ "tidak ingin mencoba memecahkan masalah menggunakan strategi lain" dapat disimpulkan bahwa DFA ingin menjawab soal dengan cara semudah mungkin dan tidak ingin mencoba cara yang lainnya. Seringkali ditemui bahwa siswa quitter lebih memilih untuk menolak ketika menemui tantangan sehingga tidak memiliki antusias ketika diberikan suatu masalah Hidayat, W., \& Sariningsih (2018).

Temuan lain adalah ketika DFA memecahkan masalah, ia seringkali mengulang bentuk bangun yang ia gambarkan dan menuliskan ukuran pada setiap sisi. Hal tersebut sejalan dengan penelitian oleh Stoltz (2000) dimana siswa quitter ketika menemui kesulitan akan lebih susah dalam mengontrol emosinya sehingga akan berdampak pada hasil pengerjaannya.

Selanjutnya subjek DSP memberikan bangun balok dan kubus dengan alasan yang tertera pada $\mathrm{O}_{4}$ pada diagram analisis wawancara, dapat diketahui bahwa DSP memilih jalan yang paling mudah yaitu memberikan bangun yang sama dengan soal. Padahal ketika dilihat pada $\mathrm{z}_{3}$ "menyebutkan beberapa alternatif strategi yakni menentukan ukuran bangun awal untuk mencari volumenya, dari volume yang diketahui tersebut dicari perkalian tiga angka atau dapat dengan menentukan ukuran bangun awal untuk dicari volumenya, untuk selanjutnya dipilih ukuran tingginya tetap sehingga hanya dicari perkalian dua angka saja" lalu $\mathrm{z}_{5}$ "mencari strategi lain" dan $\mathrm{o}_{2}$ "memberikan strategi yang lain lagi yakni bangun kubus karena hanya tinggal mencari akar pangkat tiga dari volume bangun awal" dapat dilihat bahwa DSP sebenarnya cukup produktif dalam memunculkan ide dan mampu menggunakan strategi lain, namun pada akhirnya dipilih strategi berbeda lagi yakni bangun kubus dengan alasan adalah karena dianggapnya mudah. Hal ini sejalan dengan penelitian Stoltz (2000) dimana dikatakan bahwa siswa camper akan cepat merasa puas pada saat memecahkan masalah. Sehingga meski bisa menggunakan strategi lain, DSP lebih memilih bangun yang dianggapnya paling mudah.

Temuan lain adalah ketika mengerjakan DSP seringkali melakukan pegecekan ulang karena ragu dengan hasil pengerjaannya, hal ini disebabkan siswa yang tergolong sangat kreatif dalam memecahkan masalah akan menggunakan imaginasi dan juga instuisinya serta mengaitkan pengetahuan yang satu dengan yang lainnya Johnson (2002).

Pada subjek AT, melalui $\mathrm{z}_{3}$ "Menyebutkan dan menjelaskan setiap langkah pada strategi yang 
dipilih yakni menentukan kemungkinan bangun yang dapat dijadikan kolam (balok, kubus, prisma, limas), menentukan ukuran balok pada soal sesuai dengan perbandingan, mencari volume balok pada soal, lalu mencoba-coba perkalian beberapa angka sesuai dengan rumus bangun yang dibuat" dan $\mathrm{O}_{4}$ berupa hasil dari pemecahan masalah dapat diketahui bahwa AT juga mempertimbangkan konteks pada soal ketika memecahkan masalah. Hal tersebut tidak dilakukan oleh siswa quitter maupun camper. Dapat dilihat pada $\mathrm{o}_{3}$ "Menggunakan strategi pertama yakni menentukan bentuk bangun yang mungkin untuk dijadikan kolam, lalu menentukan ukuran bangun awal untuk mencari volumenya, dari volume yang diketahui tersebut dicari perkalian beberapa angka sesuai dengan rumus bangun yang akan dibuat" dapat dilihat dalam memecahkan masalah, AT memilih strategi yang termasuk kompleks dan mengesampingkan untuk pemilihan strategi yang kedua karena meski lebih mudah ia merasa ragu dengan keakuratannya. Siswa climber akan selalu berusaha dalam memecahkan suatu masalah yang telah diberikan Suhartono (2017). Pada penelitiannya, Stoltz (2000) juga berpendapat bahwa siswa climber memiliki sifat yang gigih, ulet, tabah, dan selalu bekerja keras.

\section{KESIMPULAN}

Hasil penelitian menunjukkan siswa quitter melakukan proses berpikir kreatif pada tahap membangun ide yakni dengan menghubungkan konsep pengetahuan yang hanya ia miliki sebelumnya dimana konsep tersebut berhubungan dengan masalah yang disajikan, kemudian pada tahap menerapkan ide diambil keputusan menyerah dibanding mencoba strategi yang lain. Siswa camper melakukan proses berpikir kreatif pada tahap mensintesis ide yakni dengan memisahkan antara informasi yang dianggap penting dan informasi yang dianggap kurang penting meski tidak memperhatikan konteks pada masalah, pada tahap merencanakan penerapan dilakukan dengan memberikan rancangan yakni menghubungkan informasi penting yang telah didapatkan dengan konsep pengetahuan yang ia miliki sebelumnya secara sederhana, lalu pada tahap menerapkan ide dilakukan dengan mencoba memberikan strategi lain lagi yang dianggapnya lebih mudah. Siswa climber melakukan proses berpikir kreatif pada tahap mensintesis ide yakni dengan menandai dan menuliskan kembali informasi yang dianggap penting serta memperhatikan konteks, pada tahap membangun ide dilakukan dengan menghubungkan konsep pengetahuan yang telah ia miliki dilengkapi dengan pengetahuan pada buku, pada tahap merencanakan penerapan dilakukan dengan memberikan dua rancangan strategi penyelesaian yang akan ia gunakan dengan kompleks berdasarkan informasi dan pengetahuan yang telah didapat sebelumnya, dan pada tahap menerapkan ide dilakukan dengan memberikan pembuktian dari pemecahan masalah yang ia lakukan menggunakan dua strategi berbeda dengan jawaban akhir yang sama sekaligus tetap memperhatikan konteks.

Hasil penelitian menunjukkan bahwa subjek quitter dalam tahap menerapkan ide kurang memiliki antusias dalam mengeksplor idenya, sehingga seorang guru dapat memberikan motivasi yang lebih kepada setiap siswa dengan AQ quitter. Selanjutnya pada subjek camper dalam tahap mensintesis ide kurang memperhatikan konteks dan pada tahap menerapkan ide masih memilih 
Proses Berpikir Kreatif Siswa SMP dalam Memecahkan Masalah Numerasi Ditinjau dari Adversity Quotient (AQ), Vania

strategi yang dianggap paling sederhana, sehingga seorang guru dapat memberikan lebih banyak latihan pemecahan masalah yang berkaitan dengan kehidupan sehari-hari. Kepada peneliti yang lain, dapat mengajukan pertanyaan lain yang belum diajukan sehingga proses berpikir kreatif siswa dapat lebih diketahui secara mendetail.

\section{UCAPAN TERIMA KASIH}

Peneliti mengucapkan terima kasih kepada semua pihak yang tidak dapat disebut satu persatu dalam membantu terlaksananya penelitian ini. Terimakasih kepada orang tua dan adik peneliti yang selalu memberi doa serta dukungan. Terimakasih kepada Kepala Sekolah dan Guru Matematika SMPN 4 Pare yang telah mengizinkan untuk melakukan penelitian. Terimakasih kepada Prof. Dr. Tatag Yuli Eko Siswono, M.Pd. selaku dosen pembimbing yang membantu proses penelitan hingga akhir.

\section{REFERENSI}

Briggs, M. \& Davis, S. (2007). Creative Teaching: Mathematics in The Early Years and Primary Classroom (1st ed.). https://doi.org/https://doi.org/10.4324/9780203826294

Csikszentmihalyi, M. (1997). Creativity: Flow and the psychology of discovery and invention. NY: Harper Collins Publishers. https://g.co/kgs/Umfmsk

Dahar, R. . (2011). Teori-teori Belajar dan Pembelajaran. Erlangga.

Hidayat, W., \& Sariningsih, R. (2018). Kemampuan pemecahan masalah matematis dan adversity quotient siswa SMP melalui pembelajaran open ended. JNPM (Jurnal Nasional Pendidikan Matematika), 2(1), 109-118. https://doi.org/10.1016/S0962-8479(96)90008-8

Innovation, I. L. (2001). Creativity and Creative Thinking.

Johnson, E. B. (2002). Contextual teaching and learning: What it is and why it's here to stay. Corwin Press.

Krulik, Stephen, Rudnick, Jesse \& Milou, E. (2003). Teaching Mathematics in Middle School. Pearson Education. Inc.

McGregor, D. (2007). Developing Thinking; Developing Learning. https://books.google.co.id/books?id=WHuGYUIUMosC\&dq=mcgregor+2007+creativity\&lr=\&s ource=gbs_navlinks_s

Michael Askew, Alison Millett, M. B. (2004). The impact of the National Numeracy Strategy in Year 4: (1) Learning. RESEARCH IN MATHEMATICS EDUCATION, 6, 175-190.

Puspitasari, R. D., \& Sulaiman, R. (2019). The Profile Of Students' Thinking In Solving The Tasks of Mathematical Induction Seen From Mathematical Ability. Jurnal Ilmiah Pendidikan Matematika, $8(2)$, $181-185$.

https://jurnalmahasiswa.unesa.ac.id/index.php/mathedunesa/article/view/25554/23429

Siswono, T.Y.E. (2002). Proses Berpikir Siswa dalam Pengajuan Soal. Konferensi Nasional 
Matematika XI, 22-25.

Siswono, Tatag Yuli Eko. (2008). Proses Berpikir Kreatif Siswa Dalam Memecahkan dan Mengajukan Masalah Matematika. Jurnal Ilmu Pendidikan, Februari, 60-68. http://journal.um.ac.id/index.php/jip/article/view/13/332

Steen, L. A. (2002). Quantitative Literacy: Why Numeracy Matters for Schools and Colleges: The Third R in Literacy. Focus, 22(2), 8-9.

Stoltz. (2000). Adversity Quotient: Mengubah Hambatan Menjadi Peluang. PT Grasindo.

Sudarman. (2011). Proses Berpikir Siswa SMP Berdasarkan Adversity Quotient (AQ) dalam menyelesaikan Masalah Matematika. Universitas Negeri Surabaya.

Suhartono. (2017). Adversity Quotient Mahasiswa Pemograman Skripsi (Adeversity Quotinet of Student Programming Thesis). Matematika Dan Pembelajaran, 5(2), 209-220. 